\title{
NOTES AND NOTICES
}

\section{TIE NAE OF THE BULLETIN}

THE NAME finally adopted for this publication is THE INTER NATTONAL BULUUTIN OF BACTERI OLOGICAL NOMONCLATURE AND TAXONOMX. There are those who have felt that it would have been wiser to use MICKOBIOLOa. ICAI. rather than BACCERIOLOAI CAi. The sponsoring organiza: tion is the INTENNATIONAL. ASSOCIATION OF MICROEIOLOCISTS The term microbiology includes several disciplines, among them tacteriology, virology, mycology, al gology, ard proto zoology At the International Microbiologicai Congresses sections are constituted in these various fields.
The International Code of Bacteriological Nomenclature formally reserved primary consideration of bacterial and virus nomenclature: It like. wise recognized the primary interests of botany and zool. ogy in the nomenclature and taxonomy of the other sub. divisions of microbiology; and proposed that new opinions would be issued in these fields only when approved by the appropriate nomenclatural or taxonnmic cormission. The Editorial Board of the BULLETIN decided to use the more re" stricted term. Comments from readers as to the wisdom of this decision will be welcomed.

ADRRESSES OF

\section{MEMBERS OF THE INTERNATIONAL COMMTTIEE ON BACTERIOLOGICAL NOMENCLATURE}

The permanent secretaries and the Chairmen of the Com mittee and of the Commission must have correct address of members to make sure that correspondence may be carried forward satisfactorily. Lists of names and addresses will be found on the back cover page.
Some addresses are incomplete and others may be out of date. Will members please examine the list with care and, if any errors are noted," send correc.. tions to the Fititor: Room 24, Curtiss Hall, Ames, Iowa U. SA

\section{CHANGES IN MEMRERSHIP OF THE}

\section{INTERNATTONAL CONMTTTEE ON BACTERIOLOGICAL NONENCLATURE}

With deep regret the Com mittee notes that the follow. ing members have died since the meeting in Copenhagen in 1947 Denmark Prof $S$ Orla Jensen: Great Britain and Northern Ireland, Mr. P. Bruce White: United States of Amer ica Col A Parker Hitchens: France Prof M. Langeron. Dr Orla-jensen was al so a member of the Judicial Commission.

The resignations of $\mathrm{Dr} . \mathrm{E}$. V." Koegh (Australia), Dr. A C Thaysen (Great Britain and Northern Irel and) Professor Alfred Pettersson and Prof. Chi. Barthel (Sweden). Prof W. L Holman (Canada) were received and accepted with regret

New members were added to the Commit tee as follows: Dr V D B Skerman (Australia); Prof. Hermann Chiari. Prof. Szylvini. Prof. Krenn, Prof. Eisler Terramare (Austria)? Dr A. Bitancourt: Dr. Os"raldo Cruz fillo, Dr, A. Martins Penha, Dr $F$ de Paula da Rocha Lagóa (Brasi1) Dr. A.C. Thaysen (British West Indies); Dr. A G Lochhead. Dr. C.E $y$ an Rooyen (Canada). Prof J. Grskov, Prof N I Buchwald (Lenmark). Dr H. Vaccaro (Chile); Dr $\mathbf{P}$ Lepine, Dr Segretain (France)? Prof. Eduard Broecker: Frof $M$ Seelema 


\section{INTERNATIONAL BULLETIN}

Germany): Dr. S.T. Cowan, Dr. C. H. Andrewes (Great Britain and Northern Ireland); Prof. G Ifilphers: Prof. Sven Gerd. Prof. Reguar Nilsson (Sweinn):
Prof $T$ Wikèn (Switzer land); Prof. O. N. Allen (Uiited States of fmerice)

\section{ACKNOWLEDGEMENT OF FINANGI AJ SUPPORT}

The Editorial Board acknow ledges with sincere thanks several subventions which have made possible the pub lication of this BUTElin These are from The Trust ees of Trust Fund of the Bergey s Manual of Determin ative Bacteriology Tie Society of Gene $x$ al Microbiolous of Great Bricain through its Joint Honorery Secretary. Dr. J $G$ Devis: The Editorial Boare of the Graduate School of the lowa State College. Anes lowe. U $S$. througin its
Chairman, Dean Relpi: M, Hixon: anci the Society of American Bacteriologists through the Council of the Society and its Secretary Dr. Henry $W$ Sctrerp Somewhat less iirectly: material aid is being received from the United Nations Educetional. S:ientific and Cultural Organization through a sub. vention for the support of the clerical ano other routine expenses of tie Interuational Commitee and of the Judicial Comnission

OMATTIFE HOP FUNI FOR TIS: EICEUI INERNETIONAL BOTANICA. CONGESS.

A special Combittee for Fungi was appointed at the Stockholn Botanical Congress to study problems of nomencloture in the Fungi to serve until the close of the eighth Congress to be hold in Faris in 1554. Two of the menbers appointex $F$ Ciferri and J. Kassibation are also menters of the Internn tional Comnittee on Hucter $\dot{x}$. olngical Nomenclature. The names of the Compittee ror Fungi are as follows $D i$. Rogers, (U.S. A, ) Secretary G L. Hi sisy, (Englanel) $K I:$
Boedijn (Indonesio). R. Ciferti (Italy). K.A Donik (Inónesia). C.W. Ermons (U.S.A , J.W. Grove (Canada) $R$ Pain (France). H Jirstad (Norway I Lerijouw (llollanc). $X$ Lesel (France), f. lindrist (Argentina). W j Lutjeherms (Union Wo. Af $r$ ), G F Hartin (U S k. ) J.A.

Narmfelit (Sweden), J Nams battan (England). $\dot{k}$. Singer (Argentina) I. A. Stcvenson (U. A.). H. Trotter (Italy). E It Wakefielí (Englaid). $S$ Wiltshire (ingland).

\section{PKCOOSA: hUK AMTSIMTRI}

In a recont letter to $\mathrm{Dr}$ R. S. Breed, Permanent Siec retery of the Comitiec. Dr. 4. . Prevot writes as fóljows"

\footnotetext{
igur ce qui est du Corle et de ses anellorstions, j en gi une $a$ vous proposer
}

Princine additionel: Tout auteur décrivant une espece nouvelle dait dosigner ie genre euquel ello pppartin. ent: tout auteur decrivant une genre nuuveau doit désiguer 1 a fanille $\mathrm{a}$ laquelie il appertiner $\mathrm{l}$ tout euteur riecreivant une famille norvel le doit designer l'ordre auqial elle appartinent.

Ce principe èvitera le danger que cont courir les. bacteriojogistes Ia system at ique quand ils derrivent un taxon sans le situer riaris fe taxen d'tchelon supdrieur auquel il appartinent

Tre Eritoriel Bora will be glad to receive any coments or suegestions before prena rafion of a Preliminary Seate ment 